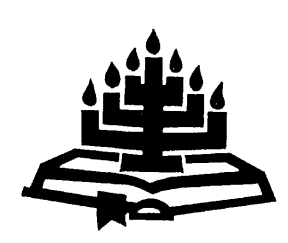

\title{
Leë plekke in die literatuur en Bybelvertaling
}

\author{
A.H. Snyman \\ Akademiese Beplanning en Ontwikkeling \\ Technikon Vrystaat \\ BLOEMFONTEIN \\ E-pos: asnyman@tofs.ac.za
}

\section{Abstract}

Empty spaces in literature and Bible translation

Texts and sentences contain empty spaces which have to be filled by readers in the construction of meaning. The way in which these spaces are filled is not completely arbitrary. Readers fill them on the basis of the textual context and/or their own field of reference. There are thus limits and constraints of interpretation.

The purpose of empty spaces is to involve the reader actively in the process of interpretation and the generation of meaning. Translators should therefore be careful to fill the empty spaces of the original text. Only in cases where it is absolutely unclear how they should be filled can the translator assist the reader in filling them. One such example is Galatians 2:4.

By filling most of the empty spaces, the translators of the 1983 Afrikaans translation weakened the communication function of the text. Examples are Ephesians 1:3-14, Romans 5:12-17 and Galatians 2:6. On the other hand, the 1983 translation is much more intelligible and accessible to the everyday reader than its predecessors.

The solution for a possible new Afrikaans translation lies somewhere between the 1933/1953 and the 1983 translations.

\section{Opsomming}

Leë plekke in die literatuur en Bybelvertaling

Tekste en sinne bevat leë plekke, wat deur die leser gevul moet word in die konstruksie van betekenis. Die wyse waarop die leë plekke ingevul word, is nie volkome arbitrêr nie. Lesers vul dit in op grond van die tekstuele konteks en/of hulle eie verwysingsveld. Daar is dus grense en beperkinge in interpretasie. 
Die doel van leë plekke is om die leser aktief betrokke te kry by die interpretasieproses en die generering van betekenis. Vertalers moet dus versigtig wees om leë plekke in die oorspronklike teks te vul. Slegs wanneer dit absoluut onduidelik is hoe die plekke gevul moet word, kan die vertaler die leser help om hulle te vul. Een voorbeeld hiervan is Galasiërs 2:4.

Deur die meeste leë plekke te vul, het die vertalers van die 1983Afrikaanse vertaling die kommunikatiewe funksie van die teks verskraal. Voorbeelde is Efesiërs 1:3-14, Romeine 5:12-17 en Galasiërs 2:6. Aan die ander kant is die 1983-vertaling meer verstaanbaar en toeganklik vir die gewone leser as sy voorgangers.

Die oplossing vir 'n moontlike nuwe Afrikaanse vertaling is geleë tussen 1933/1953 en 1983-vertalings.

\section{Inleiding}

By 'n simposium oor Bybelvertaling, wat van 20 tot 22 Augustus 2001 te Kemptonpark gehou is, het Heilna du Plooy 'n referaat gelewer met die titel: "Listening to the Wind in the Trees: Meaning, Interpretation and Literary Theory" (nog nie gepubliseer nie). Die voordrag het aangesluit by haar intreerede van 27 Oktober 2000 oor: "Die beduidende leegtes van die literatuur." In albei voordragte het sy dit oor die interpretasie van tekste - histories en teoreties deeglik begrond - en die beperkinge in die interpretasieproses. Die voordrag by die Bybelvertalingsimposium het ook 'n gedeelte oor vertaling en formulering ingesluit - aspekte wat relevant was vir die doel van die byeenkoms.

Du Plooy gaan uit van die feit dat taal altyd meerduidig is en vra in albei voordragte hoe betekenis in die literatuur tot stand kom. Ten einde die vraag te beantwoord, bepaal sy haar by slegs een aspek van betekenisgenerering, naamlik die leë plekke in die literatuur: "daardie areas en eienskappe van onbepaaldheid en vloeibaarheid in die literatuur self en in die prosesse van kommunikasie, wat rondom estetiese tekste plaasvind" (Du Plooy, 2000:4). Die plekke van onbepaaldheid, die oop plekke, geld vir woorde en woordreekse (waar die betekenis op grond van die gaping tussen betekenaar/woord en betekende/saak arbitrêr is), asook vir die strukturele oop plekke (waar die teks dinge weglaat en aan die leser geleentheid bied om die leë plekke kreatief te vul). Sy vind haar teoretiese begronding hoofsaaklik in die werke van De Saussure en Iser, aangevul deur Umberto Eco se opmerkings oor die beperkinge en grense wat die tekstuele konteks plaas op die wyse waarop die leë plekke gevul word.

Die doel van hierdie artikel is om die begrip van leë plekke te bestudeer en te wys op die implikasies daarvan vir Bybelvertaling. In die eerste 
deel word die teorie wat Du Plooy in haar werk gebruik, opgesom en saaklik geëvalueer, terwyl die tweede deel handel oor die identifisering van leë plekke in enkele Skrifgedeeltes. Die wyse waarop die leë plekke in verskillende vertalings gevul is/nie gevul is nie, word bespreek en die implikasies daarvan vir die kommunikasie van die teks uitgewys.

\section{Teoretiese begronding}

Die laaste paar dekades van die twintigste eeu was vir die literatuurwetenskap 'n periode van omvangryke ontwikkeling en verandering. Die algemene tendens in die ontwikkelinge was 'n soort demokratiseringsproses, waarin die fokus verskuif het van die teks na die leser. Die regte van die leser is beklemtoon, selfs oorbeklemtoon. Tans keer die pendulum weer terug na die teks en word gevra dat die verhouding tussen teks en leser - en veral die status van literatuur as literatuur weer krities bekyk moet word. 1

Die raamwerk vir bogenoemde teoretiese besinning is natuurlik die onvaste verhouding tussen taal en werklikheid, wat in verband gebring kan word met die werk van die Switserse taalkundige Ferdinand de Saussure. Volgens Du Plooy (2000:6) is kennis van De Saussure se definisie van die taalteken noodsaaklik om die teorieë en variasies op teoretiese konsepte, wat die laaste helfte van die twintigste eeu oorheers het, te verstaan. Vir De Saussure is die taalteken tweeledig: dit verbind 'n saak in die werklikheid (die betekende of signifié) met 'n woord (die betekenaar of signifiant). Een saak kan egter deur verskillende woorde aangedui of beteken word, terwyl een woord weer verskillende sake of variasies van 'n saak kan oproep. Die verhouding tussen betekenaar (woord) en betekende (saak) is dus nie 'n een-eenduidige verhouding nie. Verder word dieselfde saak in verskillende tale met verskillende woorde aangedui, sonder dat die saak self verander. Ten einde betekenis moontlik te maak, moet daar eers 'n ooreenkoms of konvensie tussen die sprekers van 'n betrokke taal bestaan dat sekere tekens (woorde) sekere sake sal aandui. Daar moet dus kodes in werking tree. Die kodes maak dit moontlik om op grond van ooreenkomste en verskille tussen tekens betekenis te kan herken (De Saussure, 1966:67).

Die konsekwensie van De Saussure se argument is dat die gaping tussen betekenaar (woord) en betekende (saak) 'n ruimte of opening bied, waarin die verband tussen woord en saak kan varieer. Dit is juis hierdie variasiemoontlikheid, die polisemie van taal, wat skrywers uitbuit

1 Vergelyk Eco (1990); Du Plooy (2000 \& 2001). Du Plooy (2000:40) verwys ook na die werke van Bradford (1993); Harrison (1991) en Harris (1996) wat aandag vra vir die grense van betekenis. 
wanneer 'n woord of reekse woorde doelbewus so gebruik word dat dit meer as een betekenis sal hê. Verder is woorde nie net semanties bepaal nie, maar kan hulle in sintaktiese en groter strukturele patrone ingepas word om die estetiese kwaliteit van 'n teks te verhoog (Du Plooy, 2000:7).

Volgens Du Plooy (2000:7-8) kan aangetoon word dat die opening of speling tussen teken en betekenis in die twintigste-eeuse teorieë al meer prominent geword het en dat dit verband hou met die status van die teks teenoor die status van die leser (interpreteerder). Die verband blyk duidelik uit vrae soos die volgende: Is die intensie van die aanvanklike outeur ' $n$ faktor in die bepaling van betekenis, of is die teks los van die outeur soos die teken van die saak? Het die outeur nog enige gesag oor die teks as dit gepubliseer is en eeue later gelees word, of is die teks iets wat net in die leesproses tot stand kom? Word betekenis gegenereer tussen teks en leser, of ontstaan dit net by die leser omdat die teks nie die oorspronklike betekenis van die woorde waaruit dit bestaan, kan bewaar nie? Skerp en indringende vrae, wat ook deel was (en is) van die debat binne die Nuwe-Testamentiese hermeneutiek.

Wat wel duidelik is uit Du Plooy se argument, is dat die klem gedurende die twintigste eeu al meer verskuif het van die teks na die leser. Dit blyk duidelik uit die resepsie-georïenteerde teorieë van Ingarden, Gadamer en andere (vgl. Zima, 1999:73). Binne hierdie tradisie het Wolfgang Iser (1974:37) sy siening van die sogenaamde leë plekke geformuleer, wat Du Plooy (2000:10-11) soos volg omskryf:

Hierdie konsep (leë plek) hou wel verband met die gaping tussen taalteken en betekenis, maar het ook en veral strukturele betekenis. Net soos wat die woord onbepaald is, is daar ook in die teks onbepaaldhede, oop plekke, onvertelde of onuitgesproke dele. Alle skryf impliseer seleksie en geen teks kan iets volledig weergee nie. Skrywers benut natuurlik ook hierdie eienskap van taaltekste en gebruik dikwels weglatings juis om die leser te boei. Die leser mag en moet self daardie ooptes vul, op grond van die tekstuele konteks, maar ook op grond van sy eie verwysingsveld en uitgaande van sy eie konteks (kursivering, AHS).

Veral laasgenoemde kursivering is belangrik, omdat dit beklemtoon dat die leser nie volkome vry is om die ooptes te vul nie. Hy word beperk deur die tekstuele konteks en sy eie verwysingsraam. Volgens Umberto Eco (1990:6) is die regte van die leser teen die einde van die twintigste eeu oorbeklemtoon en is dit nou nodig om die regte van die teks te verdedig. Die interpretasie en resepsie van die teks is nie totaal arbitrêr nie. Volgens Zima (1999:189-213) moet interpretasie gerig word deur: 
- die fonetiese, sintaktiese, semantiese en narratiewe strukture van tekste, en

- die groter kontekstuele raamwerke van die leser.

Saamgevat: Die oop plekke in die literatuur bied aan die leser die geleentheid om kreatief te interpreteer. Dit maak hom deel van betekenisgenerering en hou hom aktief en denkend in die leesproses. Lesers vul die oop plekke in op grond van die tekstuele konteks of hulle eie verwysingsveld. So het die (binne- of buite-) tekstuele konteks byvoorbeeld implikasies vir die religieuse relevansie van 'n interpretasie van 'n Nuwe-Testamentiese teksgedeelte.

\section{Vertaling en formulering}

Nadat 'n teks geïnterpreteer is, is dit die taak van die vertaler om dit toeganklik te maak vir die lesers in die doeltaal. Du Plooy (2001) wys op die verantwoordelikheid wat dit plaas op die skouers van die vertaler. Om dit te illustreer wys sy op die volgende verskille en ooreenkomste tussen interpretasies en vertalings:

- 'n Interpretasie het gewoonlik 'n kort lewensduur, 'n vertaling nie.

- 'n Vertaling is dikwels die enigste toegang wat lesers het tot 'n bepaalde teks. Die gevolg is dat die vertaling 'n soort kanonieke status verkry, soos in die geval van Bybelvertaling. Dit geld nie van die interpretasie van 'n teks in 'n lesing of wetenskaplike voordrag nie.

- Nog 'n verskil is dat die interpreteerder dikwels probeer om sy lesers/gehoor te beïndruk met sy buitengewoon oorspronklike lees van 'n teks. 'n Vertaler geniet nie dieselfde vryheid nie. Hy het nie eienaarskap van die teks nie, maar moet die beperkinge wat die teks op hom plaas, eerbiedig. Umberto Eco beskryf dit soos volg:

A text is a place where the irreducable polysemy of symbols is in fact reduced, because in a text symbols are anchored to their context ... thus many modern theories are unable to recognise that symbols are paradigmatically open to infinite meanings, but syntagmatically, that is, textually, open to the indefinite, but by no means infinite, interpretations allowed by the context. (Aangehaal deur Du Plooy, 2001.)

- Die belangrike ooreenkoms tussen die interpreteerder en die vertaler is die feit dat albei gekonfronteer is met die tekstuele aspekte van die teks: die fonetiese, semantiese, sintaktiese en narratiewe strukture daarvan, die metafore wat gebruik word en die taalregister. Al die aspekte is op sigself betekenisvol. Gevolglik is die interpretasie vir die 
interpreteerder en die vertaler nie heeltemal arbitrêr nie, maar word dit gerig deur die determinante van die bronteks.

Uiteindelik is die interpreteerder en die vertaler verantwoordelik vir dit waarmee hulle die oop plekke vul. Dit geld veral vir tekste soos religieuse tekste, wat 'n wêreld van hulle eie skep. As die interpreteerder/ vertaler ' $n$ ateïs is, sal hy nie die leë plekke in Bybelse tekste kan vul met religieuse inhoud nie; sal hy nie dit wat heenwys na die geloof, kan interpreteer en vertaal nie.

Die laaste (en moeilikste) taak van die vertaler is om sy bevindinge te formuleer: "The translator is caught between two fires, between interpretation and formulation, and he needs them both" (Du Plooy, 2001).

Du Plooy is van oordeel dat die Bybelvertaler sy taak nougeset en konserwatief moet uitvoer. Sy het meegewerk aan die nuwe beryming van die Psalms en het telkens agtergekom hoe moeilik dit is om metafore te vertaal. As die vertaler 'n metafoor verduidelik, beperk hy die betekenis daarvan deur slegs een van verskeie assosiasies/betekenisaspekte ten koste van die ander uit te lig. Die vraag is of die vertaler die reg het om dit te doen. Die 1983-vertaling bevat heelwat verduideliking, met 'n gevolglike verarming van die poëtiese gedeeltes in die oorspronklike taal.

Haar tweede vraag oor die 1983-vertaling is die wyse waarop Paulus se lang sinne herskryf is in reekse van kort sinne. Die uitgangspunt van haar argument is dat sinstruktuur betekenis genereer. Indien 'n vertaler die oorspronklike sinstruktuur wysig, kan die vertaling inboet aan betekenis. In die verbygaan het sy verwys na Efesiërs 1:3-14, waar die lang $\sin$ in die oorspronklike Grieks die oneindige vloei van geloof kan suggereer - 'n voorbeeld waarna ons hieronder terugkeer.

Die korter sinne in die 1983-vertaling hang natuurlik saam met die linguisties-gebaseerdere teorieë, wat die terrein van Bybelvertaling in die sewentiger- en vroeë tagtigerjare oorheers het. Nida en Taber (1969:12) het die konsepte "formele" en "dinamies/funksionele" ekwivalensie ingevoer. Laasgenoemde het die ontvangers van die boodskap in fokus geplaas: die vertaling moes dieselfde kommunikatiewe waarde vir die ontvangers hê as wat dit vir die oorspronklike lesers gehad het. Om ekwivalensie te bereik, moes die betekenis van 'n teks op veral die woord- en sinsvlak bepaal en in die doeltaal geherformuleer word deur middel van die sogenaamde dinamies-ekwivalente metode van vertaling.

Dat dié metode 'n belangrike bydrae gelewer het om die verstaanbaarheid van die Bybel te verhoog, ly geen twyfel nie. Dit spreek vanself dat die sinstruktuur van die oorspronklike Grieks in die proses aangepas is - 
soms drasties aangepas is. Ongelukkig het dit daartoe gelei dat die kommunikatiewe waarde van die oorspronklike sinstruktuur soms verlore gegaan het (presies dit waarop Du Plooy gewys het). Verder het dit geblyk dat die ideaal van ekwivalensie, wat so sentraal in Nida se denke staan, nie volkome haalbaar is nie, gewoon as gevolg van die taalkundige en kulturele verskille tussen tale. Die normatiewe vertaalteorieë (waaronder die dinamies-ekwivalente metode resorteer) neem nie die sosio-kulturele omstandighede waarin die vertaling geproduseer word en waarbinne dit moet kommunikeer, voldoende in ag nie. Gevolglik het daar vanaf die vroeë tagtigerjare reeds 'n skuif van 'n normatiewe (preskriptiewe) na 'n deskriptiewe werkswyse plaasgevind (Naudé, 2001:5).

Du Plooy se voordrag is nie sonder probleme nie. Dit is byvoorbeeld nie altyd duidelik wanneer 'n vertaler met ' $n$ leë plek te doen het nie en wat die funksie daarvan is nie. Die leemte is egter nie net by haar te vind nie. Die lukrake wyse waarop leë plekke as teksverskynsels in die literatuur benoem word ("gaps", "Unbestimmtheitsstellen", "woordleegtes", "empty spaces", "plekke van onbepaaldheid" ens.) onderstreep die gebrek aan 'n gestandaardiseerde ondersoekmodel vir die analise van die leë plek en sy funksies. Anderson (1996) het 'n verklaringsraam vanuit die semiotiese strukturalisme ontwikkel om die leë plek op 'n onderskeidende manier te beskryf en te verklaar. Met die ondersoekraam wil sy die aard en funksie van die leë plek in 'n teks ekspliseer, en wel op 'n wyse wat intersubjektiwiteit verseker. Die feit dat Du Plooy nêrens na die voorstel van Anderson verwys nie, beklemtoon die gebrek aan eenstemmigheid onder literatuurwetenskaplikes oor die teksverskynsel.

Die standpunt wat Du Plooy stel, bly egter belangrik vir vertalers: formulering in die doeltaal dra by tot betekenis. By die simposium in Kemptonpark was daar eenstemmigheid dat die formele en strukturele aspekte van die brontaal meer tot hulle reg moet kom in hersiene of nuwe Bybelvertalings. Christene wêreldwyd stel toenemend belang in onder andere die volgende aspekte: die wyse waarop die Bybelse tekste gestruktureer is, die skoonheid en trefkrag van digterlike gedeeltes, die retoriese kenmerke van die tekste, ensovoorts (De Blois en Mewe, 2001:1-2). Hierdie nuwe benadering erken die diversiteit in styl en genre binne die Bybelboeke en vra dat die literêre vorme, strukture en temas op een of ander wyse in die vertaalde tekste gereflekteer moet word. Dit is ook Du Plooy se benadering as sy die herstrukturering van Paulus se sinne in korter sinne bevraagteken. 


\section{Voorbeelde van leë plekke in die Skrif}

\subsection{Efesiërs 1:3-14}

Die opskrif van dié gedeelte in die Griekse teks van Aland Black et al. is: "Spiritual Blessings in Christ." Efesiërs 1:3-14 is een lang sin in die oorspronklike taal. In vers 3 is daar 'n woordspel met $\epsilon \dot{\lambda} \lambda \circ \gamma \varepsilon \dot{\varepsilon}(\omega$, wat 'n basis bied vir die verstaan van die hele gedeelte. Die eerste gebruik van

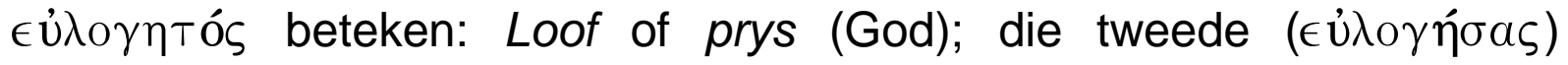
beteken: seën (Christus, wat ons geseën het met alle geestelike seëninge in die hemele). Die temas van lofprysing en geestelike seëninge wissel mekaar af, terwyl die oproep om God te prys (in 3 en 14) die gedeelte omraam.

God moet geprys word. Vier keer word die lesers opgeroep om dit te doen: In verse 3, 6, 12 en 14. Die rede vir die oproep is dit wat God in Christus gedoen het: Hy het ons verlos volgens sy soewereine wil en keuse (4a, 5, 9 en 11). Die geestelike seëninge waarin ons deel, sluit in:

- die uitverkiesing in Christus (4);

- aanneming tot kinders (5);

- verlossing deur die bloed van Christus (7);

- vergifnis van sonde (7);

- erfgename in Christus wees (11);

- die Heilige Gees as teken van Gods eiendom (13); en

- die Heilige Gees as waarborg van Gods beloftes (14).

God die Vader is die Een wat ons uitverkies (4), wat ons sy kinders maak (5), wat ons red (7) en ons sy erfgename maak (11). Christus is die Een deur Wie Hy dit alles doen $(4,5,7,11,13)$. Die Heilige Gees is die bewys dat ons die eiendom van God is (13), die waarborg dat ons alles sal ontvang wat God belowe het (14).

God se bedoeling word opgesom in 10b: "Om alles wat in die hemel en alles wat op die aarde is, onder een hoof te verenig, naamlik onder Christus." Die uiteindelike gevolg van God se plan is dat die nuwe mensheid sy lof sal verkondig (3, 6, 12 en 14) (Bratcher \& Nida, 1982:7).

Die vraag is nou of Efesiërs 1:3-14 as een lang sin vertaal moet word en of dit in korter sinne verdeel moet word. Die eerste Afrikaanse vertaling (1933) het net een breuk in die gedeelte, tussen verse 6 en 7. Die 1983vertaling het dit in veertien sinne verdeel. In die King James Version (KJV) is daar drie sinne, in die Revised English Bible (REB) agt, in die 
Good News Bible (TEV) elf, in die Contemporary English Version (CEV) vyftien en in die New International Version (NIV) agt. Uiteraard lees die korter sinne makliker en is hulle dadelik verstaanbaar. Volgens Du Plooy (2001) kon daar egter iets verlore gaan: die betekenis wat deur die lang sin in die oorspronklike taal gegenereer word. Anders gestel: die lang sin skep 'n leë plek, wat deur die vertaler met 'n reeks kort sinne gevul word. So word die leser se kreatiwiteit aan bande gelê en die betekenis van die teks verskraal.

Die een lang sin in die oorspronklike Grieks kan die stroom van geestelike seëninge, verweef met lofprysings, verbeeld (vgl. Greek New Testament, 1975). Dit kan ook die Drie-eenheid suggereer: die één God (Vader, Seun en Heilige Gees) wat geprys moet word vir sy ewige verlossingsplan. Hierdie interpretasie kan soos volg gemotiveer word: sinstruktuur genereer betekenis; dit skep 'n leë plek, wat deur die leser gevul moet word, en wel op grond van die tekstuele konteks of sy eie verwysingsveld. Gevolglik moet die vertaler versigtig wees om sinne na willekeur te verkort of aan te pas.

\subsection{Romeine 5:12-17}

Nog 'n voorbeeld van 'n leë plek is die anakoloet in Romeine 5:12, gevolg deur die uitgebreide parentese in 5:13-17. Dié paar verse vorm deel van Paulus se argument in 5:1-21, wat handel oor die implikasies van regverdigmaking deur die geloof (Louw, 1979: 143-144). In verse 1221 gaan dit spesifiek om Christus wat, op grond van sy verlossingswerk, 'n soortgelyke posisie in die mensdom inneem as Adam, wat alle mense in sonde gedompel het. Die beginsel waarop die argument berus, is dat die hele mensheid deur een persoon verteenwoordig word. Wat dus met die een gebeur, het betekenis vir al die ander (Jonker, 1969: 83).

Die hoofsin in 5:12 begin met $̋ \sigma \pi \epsilon \rho=$ "net soos" ("Net soos deur een mens die sonde in die wêreld ingekom het, en deur die sonde die dood, en so die dood tot alle mense deurgedring het"), maar die gedagte word nie voltooi nie. In plaas daarvan voeg Paulus nou 'n lang parentese in oor die gevolge van die sonde van Adam tot by Moses (5:13-14), en 'n vergelyking tussen Adam en Christus (5:15-17). Na die parentese word die hoofsin in 5:12 herhaal en voltooi in 5:18-19:

Soos een oortreding gelei het tot veroordeling vir alle mense, so het een daad van gehoorsaamheid dus ook gelei tot vryspraak en lewe vir almal. Soos baie deur die ongehoorsaamheid van een mens sondaars geword het, so ook sal baie deur die gehoorsaamheid van die een Mens vrygespreek word (NAV). 
'n Anakoloet is 'n skuif in verwagting op sinsvlak (Nida et al., 1983: 184). Op dié wyse word 'n leë plek geskep. Die vraag is of die vertaler die leë plek moet vul (dit wil sê die hoofsin in 5:12 moet voltooi) of nie. Vertalings verskil op dié punt. Die NIV, RSV en KJV behou die anakoloet. Die NIV en RSV beklemtoon dit verder met aandagstrepe, terwyl die KJV die hele parentese (5:13-17) tussen hakies plaas. Die 1933/1953 Afrikaanse vertaling het ook die anakoloet behou, met 'n aandagstreep aan die einde van 5:12. Die TEV, CEV en nuwe Afrikaanse vertaling het egter die anakoloet geïgnoreer en die sin op verskillende maniere voltooi:

- TEV: "Sin came into the world through one man, and his sin brought death with it. As a result, death has spread to the whole human race because everyone has sinned."

- CEV: "Adam sinned, and that sin brought death into the world. Now everyone has sinned, and so everyone must die."

- NAV: "Verder nog dit: Deur een mens het die sonde in die wêreld gekom en deur die sonde die dood, en so het die dood tot al die mense deurgedring, omdat almal gesondig het."

Deur die sin in 5:12 te voltooi, vul die vertaler self die leë plek in die oorspronklike. Op dié wyse gaan die verwagting wat geskep is deur $\omega ँ \sigma \pi \epsilon \rho$, asook die effek van die parentese in 5:13-17, verlore. Deur die oop plek in 5:12 te behou, kry die leser die geleentheid om kreatief te interpreteer en deel te neem aan die generering van betekenis.

In die lig van die argument in hierdie artikel word sterk aanbeveel dat vertalers nie die leë plek in Romeine 5:12 vul nie, maar dit oop laat vir die lesers.

\subsection{Galasiërs 2:3-6}

Die anakoloete in Galasiërs 2:4-6 is reeds bespreek deur Cronjé, 1986: 220-221. In dié geval is dit moeiliker om te besluit of die leë plekke, wat deur die anakoloete geskep is, gevul moet word of nie. Vertalings verskil ook op dié punt.

In die 1933/1953 Afrikaanse vertaling is die gedeelte soos volg vertaal:

3. Maar selfs is Titus, wat by my was, nie gedwing om besny te word nie, alhoewel hy 'n Griek is;

4. en dit vanweë die ingesmokkelde valse broeders ( $\delta \iota \grave{\alpha} \delta \grave{\varepsilon}$ Toùs

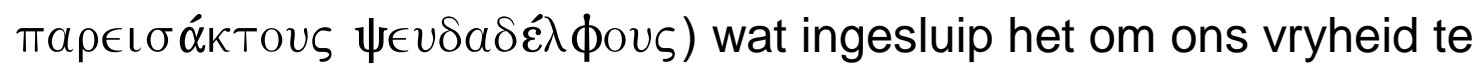


bespied wat ons in Christus Jesus het, sodat hulle ons in diensbaarheid kon bring;

5. aan wie ons selfs nie 'n oomblik in onderworpenheid toegegee het nie, sodat die waarheid van die evangelie by julle bestendig sou bly.

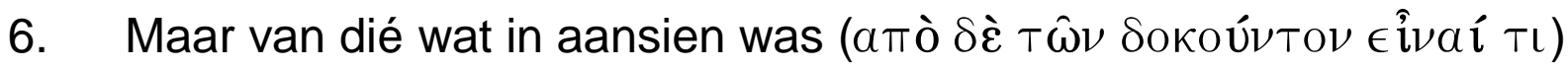
- wat hulle vroeër was, maak by my geen verskil nie; God neem die persoon van die mens nie aan nie - hulle dan wat in aansien was

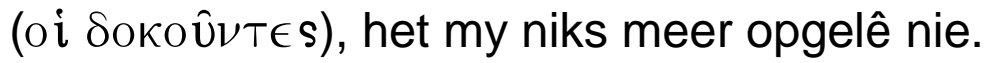

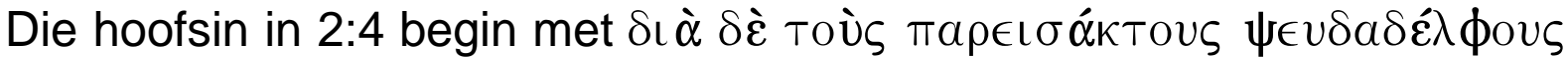
(en vanweë die ingesmokkelde valse broeders), maar word nie voltooi nie. Om sin te maak het die meeste vertalings (soos die OAV hierbo) dit verbind aan die voorafgaande gedeelte met dié betekenis: selfs Titus is nie gedwing om besny te word nie, en dit ter wille van die ingesmokkelde valse broeders. (Vir vertalings wat dit ook so interpreteer, sien Hendriksen, 1990:78.) In die Grieks is daar egter 'n kommapunt aan die

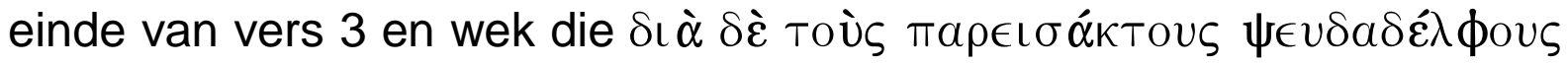
aan die begin van vers 4 die verwagting van 'n nuwe sin wat voltooi moet word. Dit gebeur egter nie, met die gevolg dat 'n leë plek in die Griekse teks geskep word.

Die breuk in die grammatikale konstruksie van vers 6 is duidelik uit die vertaling hierbo. Dit is nog 'n voorbeeld van 'n anakoloet. Paulus begin

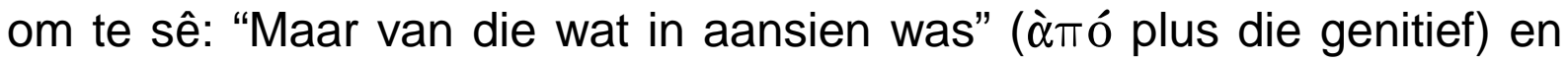
voltooi nie die sin nie. In plaas daarvan onderbreek hy homself met 'n parentese, wat uit twee kort sinne bestaan:

- dit maak nie vir my saak wat hulle was nie, en

- God neem nie die persoon van die mens aan nie.

$\mathrm{Na}$ die onderbreking keer hy terug na die onderwerp in die sin ("van die wat in aansien was"), maar voltooi dit nie. In plaas daarvan begin hy met 'n ander onafhanklike sin waarin "die wat in aansien was" (nominatief) die onderwerp vorm. Op dié wyse word nog 'n leë plek in die Griekse teks geskep, al is die inhoud waarmee dit gevul kan word (= die betekenis daarvan) duideliker as in 2:4.

Of die betekenis duidelik is of nie, dit bly leë plekke in die Griekse teks. Moet die vertaler dit vir sy lesers vul of nie? Ons argument is dat leë plekke sover as moontlik nie gevul moet word nie. In die lig hiervan kan die oop plek in 2:6 oop bly, soos die REB, die RSV, die NIV, die KJV en die 1933/1953 vertaling dit het. Die TEV en nuwe Afrikaanse vertaling 
het dit egter gevul. Wat 2:4 betref, het al die vertalings (insluitend die KJV en 1933/1953 Afrikaanse vertaling) die oop plek gevul - waarskynlik

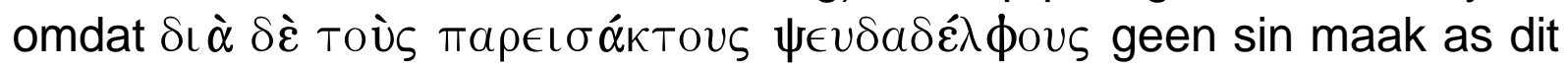
nie met die voorafgaande teks verbind word nie.

\subsection{Psalm 27:13}

Seker die bekendste oop plek in die Skrif is Psalm 27:13. In die oorspronklike taal is dit 'n voorwaarde-gevolgsin, maar die gevolg is nie uitgespel nie. Die partikel in die oorspronklike lui 'n negatiewe irreële voorwaarde in. Die apodosis van die voorwaardesin ontbreek egter (Van der Merwe et al., 1997:248). Die verskillende vertalings lees soos volg. (Dit waarmee die leë plek gevul is, word tussen hakies geplaas):

- KJV: (I had fainted,) unless I had believed to see the goodness of the Lord in the land of the living.

- REB: (Well I know) that I shall see the goodness of the Lord in the land of the living.

- RSV: (I believe) that I shall see the goodness of the Lord in the land of the living.

- CEV: (But I know) I will live to see how kind You are.

- TEV: (I know) that I will live to see the Lord's goodness in this present life.

- NIV: (I am still confident of this): I will see the goodness of the Lord in the land of the living.

- OAV (1933/1953): O, as ek nie geglo het dat ek die goedheid van die Here sal sien in die land van die lewendes nie ...

- NAV: As ek darem nie geglo het dat ek die goedheid van die Here sal sien in die land van die lewendes nie ...!

Uit bogenoemde is dit duidelik hoe 'n vertaler die betekenis van 'n oorspronklike teks kan verskraal deur self 'n leë plek te probeer vul.

\section{Konklusie}

Binne die Duitse tradisie van Ingarden, Gadamer en Jauss het Wolfgang Iser sy siening oor die sogenaamde leë plekke geformuleer. Die siening hou verband met die gaping tussen taalteken en betekenis - ook en veral strukturele betekenis. Net soos wat die woord onbepaald is, is daar ook in die teks onbepaaldhede of leë plekke, wat die leser self moet vul op grond van die tekstuele konteks en sy eie verwysingsveld. Laas- 
genoemde impliseer dat die leser nie volkome vry is om die oop plekke te vul nie.

Nadat 'n teks geïnterpreteer is, moet die vertaler dit toeganklik maak vir die lesers in die doeltaal. Die vraag is of die vertaler die oop plekke moet vul en of hy dit aan die leser moet oorlaat om dit te doen. Om dié vraag te beantwoord moet die teikengroep vir wie die vertaling bedoel is natuurlik verreken word. As algemene riglyn geld egter dat die vertaler die leë plekke oop moet laat tensy dit glad nie duidelik is hoe dit gevul moet word nie. Oop plekke wat so gelaat behoort te word, is Efesiërs 1:3-14, Romeine 5:12-17, Galasiërs 2:6 en Psalm 27:13. In Galasiërs 2:4 kan die vertaler die leser help, omdat dit glad nie duidelik is hoe die oop

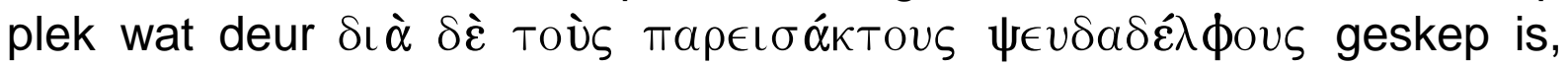
gevul moet word nie.

In die 1983-Afrikaanse vertaling is die oop plekke in Efesiërs 1:3-14, Romeine 5:12-17 en Galasiërs 2:6 almal gevul. Die voorstel is dat sulke dele hersien word in 'n moontlike nuwe Afrikaanse vertaling van die Bybel.

Uiteindelik is dit nodig dat die aard en funksie van die leë plekke as teksverskynsel verder ondersoek moet word. Literatuurwetenskaplikes moet ooreenkom op 'n gestandardiseerde raamwerk vir die analise van die leë plek en sy funksies. Die waarde van Du Plooy se voordrag is juis dat sy die leë plek op die agenda van Bybelvertaling geplaas en die noodsaak van so 'n verklaringsraam geïllustreer het.

\section{Bibliografie}

\section{Lys van afkortings vir Bybelvertalings:}

TEV = Today's English Version

CEV = Contemporary English Version

NAV = Nuwe Afrikaanse Vertaling

REB = Revised English Bible

$\mathrm{KJV}=$ King James Version

NIV = New International Version

$\mathrm{OAV}=\mathrm{Ou}$ Afrikaanse vertaling

ANDERSON, N. 1996. Die leë plek: 'n genologiese onderskeiding. Tydskrif vir Literatuurwetenskap, 12(3):248-274.

BRATCHER, R.G. \& NIDA, E.A. 1982. A translator's handbook on Paul's letter to the Ephesians. London : United Bible Societies.

BYBEL, Die. 1933. Kaapstad : Bybelgenootskap van Suid-Afrika.

BYBEL, Die. 1953. Kaapstad : Bybelgenootskap van Suid-Afrika.

BYBEL, Die. 1983. Kaapstad : Bybelgenootskap van Suid-Afrika.

CONTEMPORARY ENGLISH VERSION. 1995. Nashville : Thomas Nelson. 
CRONJÉ, J.v.W. 1986. Defamiliarization in the Letter to the Galatians. (In Petzer, J.H. \& Hartin, P.J., eds. A South African perspective on the New Testament. Essays by South African New Testament scholars presented to Bruce M. Metzer. Leiden : Brill. p. 214-227.)

DE BLOIS, K.F. \& MEWE, T. 2001. Functional equivalence and the new Dutch translation project. Kemptonpark. Referaat by Simposium oor Bybelvertaling.

DE SAUSSURE, F. 1966. Kursus in algemene taalkunde. Vertaling deur Alewyn Lee. Pretoria : Van Schaik.

DU PLOOY, H. 2000. Die beduidende leegtes van die literatuur. Potchefstroom. Wetenskaplike bydraes, Reeks $\mathrm{H}$ : Inougurele rede $\mathrm{nr} .166$.

DU PLOOY, H. 2001. Listening to the wind in the trees: meaning, interpretation and literary theory. Kemptonpark. Referaat by Simposium oor Bybelvertaling.

ECO, U. 1990. The limits of interpretation. Bloomington : Indiana University Press.

GREEK NEW TESTAMENT, The. 1975. New York : United Bible Societies.

HENDRIKSEN, W. 1990. Galatians and Ephesians. Trowbridge, Wiltshire : The Camelot Press.

ISER, W. 1974. The implied reader. Baltimore : The John Hopkins University Press.

JONKER, W.D. 1969. Die Brief aan die Romeine. Kaapstad: N.G. Kerk Uitgewers.

KING JAMES VERSION. 1982 [1611]. Second South African edition. Parow : CTP Book Printers.

LOUW, J.P. 1979. A semantic discourse analysis of Romans. Volume II. Pretoria : Pretoria University, Department of Greek.

NAUDÉ, J.A. 2001. An overview of recent developments in translation studies with special reference to the implications for Bible translation. Kemptonpark. Referaat by simposium oor Bybelvertaling.

NEW INTERNATIONAL VERSION. 1985. Goodwood : NBD.

NIDA, E.A., LOUW, J.P., SNYMAN, A.H., CRONJé, J.v.W. 1983. Style and discourse, with special reference to the text of the Greek New Testament. Roggebaai : Bible Society of South Africa.

NIDA, E.A. \& TABER, C. 1969. The theory and practice of translation. Leiden : Brill.

REVISED ENGLISH BIBLE, The. 1989. Oxford : Oxford University Press.

REVISED STANDARD VERSION. 1980. Goodwood : NBD.

TODAY'S ENGLISH VERSION. 1993. Goodwood : NBD.

VAN DER MERWE, C.H.J., NAUDÉ, J.A., KROEZE, J.H. 1997. Bybels-Hebreeuse Naslaangrammatika. Kaapstad : Nasionale Boekdrukkery.

ZIMA, P.V. 1999. The philosophy of modern literary theory. New Brunswick : Athlone Press.

\section{Kernbegrippe:}

Bybelvertaling dinamiese/funksionele ekwivalensie formulering en betekenis interpretasie en formulering leë plekke 


\section{Key concepts:}

Bible translation

dynamic/functional equivalence

empty spaces

formulation and meaning

interpretation and formulation 
